\title{
P.P. Коморовський
}

Тернопільський національний медичний університет імені І.Я. Горбачевського Фундація серцево-судинних досліджень, лікарня Сан Джакомо, Кастельфранко Венето, Італія

\section{Віддалені результати інвазивної та неінвазивної стратегій лікування в пацієнтів похилого віку 3 гострим коронарним синдромом}

Мета роботи - оцінити віддалені результати консервативної та інвазивної стратегій лікування пацієнтів похилого віку із гострим коронарним синдромом у реальній клінічній практиці.

Матеріали і методи. Проведено аналіз віддалених результатів лікування 113 послідовних пацієнтів віком $\geq 70$ років із гострим коронарним синдромом. Кінцеві точки дослідження - серцева смерть або нефатальний інфаркт міокарда (IM), нестабільна стенокардія, повторна госпіталізація.

Результати. Виживання, вільне від подій (смерті, ІМ, нестабільної стенокардії або повторної госпіталізації), становило 59 \% через 20 (12-25) місяців спостереження. Частота цих подій була статистично значуще вищою $(p=0,03)$ у пацієнтів, які отримували лише медикаментозну терапію порівняно з тими, яким було здійснено аортокоронарне шунтування (АКШ), і погранично вищою $(p=0,08)$ порівняно з групою черезшкірного коронарного втручання (ЧКВ). Вільне від подій виживання між обома інвазивно лікованими групами (АКШ і ЧШКВ) статистично значуще не відрізнялося ( $p=0,81$ ). При цьому м'які події (нестабільна стенокардія, повторна госпіталізація з приводу нестабільної стенокардії) у групі АКШ спостерігалися статистично значуще рідше $(p=0,04)$ порівняно 3 групою медикаментозного лікування, а частота тяжких подій (серцевої смерті та нефатального IM) була зіставною у всіх групах. Низька фракція викиду (<40\%) та супутнє ураження периферійних артерій за даними аналізу інтенсивних пропорційностей Кокса були незалежними предикторами тяжких подій.

Висновок. АКШ у пацієнтів похилого віку ( $\geq 70$ років) порівняно з консервативною стратегією, характеризується кращим виживанням, вільним від серцевих подій.

Ключові слова: гострий коронарний синдром, вік, прогноз, реваскуляризація.

Посилання: Коморовський Р.Р. Віддалені результати інвазивної та неінвазивної стратегій лікування в пацієнтів похилого віку 3 гострим коронарним синдромом // Кардіохірургія та інтервенційна кардіологія.- 2019.- № 3.- С. 22-29.

To cite this article: Komorovsky RR. Long-term results of invasive versus non-invasive strategy in the elderly patients with acute coronary syndrome. Cardiac Surgery and Interventional Cardiology. 2019;3(26):22-29 (in Ukr.).

$\Pi$ ацієнти похилого віку ( $\geq 70$ років), яких госпіталізують із гострим коронарним синдромом (ГКС), становлять особливу групу, чисельність якої в повсякденній клінічній практиці постійно зростає [2, 9]. Ці пацієнти у клінічних дослідженнях мало представлені $(5-10 \%)[4,10]$. Насправді вони становлять приблизно третину (30-35 \%) від усіх госпіта-

лізованих із ГКС, що підтверджується даними реєстрів [4, 7], у зв’язку з чим існує проблема репрезентативності популяцій, залучених до клінічних досліджень. Питання вибору стратегії лікування пацієнтів похилого віку із ГКС та можливість застосування щодо них результатів клінічних досліджень все ще дискутується $[5,6]$. 
Фактично, при виборі оптимальної стратегії лікування необхідно враховувати не лише ймовірні безпосередні результати, а й віддалені наслідки. Ще в дослідженні TIME [13] було показано, що в пацієнтів похилого віку із симптомною ішемічною хворобою серця, попри початкову ефективність інвазивної стратегії лікування, через рік спостереження не виявляється суттєвих переваг останньої порівняно з оптимальним медикаментозним лікуванням щодо симптомів, якості життя та серцевих подій. Проте, з урахуванням пізніше проведених досліджень, сучасні європейські настанови [8, 15] рекомендують у пацієнтів похилого віку із ГКС такий само підхід, як і у молодших осіб. Водночас у реальній клінічній практиці пацієнти похилого віку рідше отримують інвазивне лікування з огляду на ризики самої інвазивної процедури, супутні захворювання, очікувану тривалість життя, а також особистий вибір, соціально-економічний статус $[6,17]$. Саме тому результати лікування пацієнтів похилого віку в реальній практиці не такі обнадійливі, як у клінічних дослідженнях, i становлять предмет обговорення [14, 20].

Мета роботи - оцінити віддалені результати консервативної та інвазивної стратегій лікування пацієнтів похилого віку із гострим коронарним синдромом у реальній клінічній практиці.

\section{Матеріали і методи}

У дослідження для проспективного спостереження залучено 113 послідовних хворих віком $\geq 70$ років, госпіталізованих з приводу ГКС у відділення загальної та інтервенційної кардіології комунальної лікарні м. Кастельфранко
Венето (Італія) протягом 2003-2005 рр. (під час стажування там автора). ГКС діагностували згідно з рекомендаціями Американської колегії кардіологів та Американської асоціації серця [1, 3]. Усім пацієнтам упродовж періоду госпіталізації виконано коронароангіографію. Після оцінки лікуючим лікарем (кардіологом), інтервенційним кардіологом (кардіохірургом) для пацієнтів обирали або інвазивну стратегію (черезшкірне коронарне втручання (ЧКВ) чи аортокоронарне шунтування (АКШ)), або консервативне (медикаментозне) лікування (рис. 1). При виборі методу реваскуляризації керувалися тогочасними настановами [1, 3], зокрема, при діагностованій нестабільній стенокардії або інфаркті міокарда (IM) без підйому сегмента ST, односудинному або двосудинному ураженні й сприятливій анатомії вінцевих артерій схилялися до вибору ЧКВ, при виявленні багатосудинного ураження, значущого ураження стовбура лівої вінцевої артерії пацієнтам пропонували АКШ. При діагностованому IM з підйомом сегмента ST за умови своєчасної госпіталізації виконували ЧКВ на інфарктзалежній артерії, при несприятливій для ЧКВ анатомії вінцевих артерій або пізній госпіталізації та персистуванні симптомів ішемії розглядали можливість АКШ. Стратегія лікування не змінювалася протягом періоду спостереження. Критеріями вилучення були гемодинамічно значущі клапанні вади серця та неішемічна серцева недостатність.

Усі пацієнти дали згоду на участь у дослідженні. Після вибору стратегії лікування інформацію про віддалені результати реєстрували впродовж періоду спостереження шляхом теле-

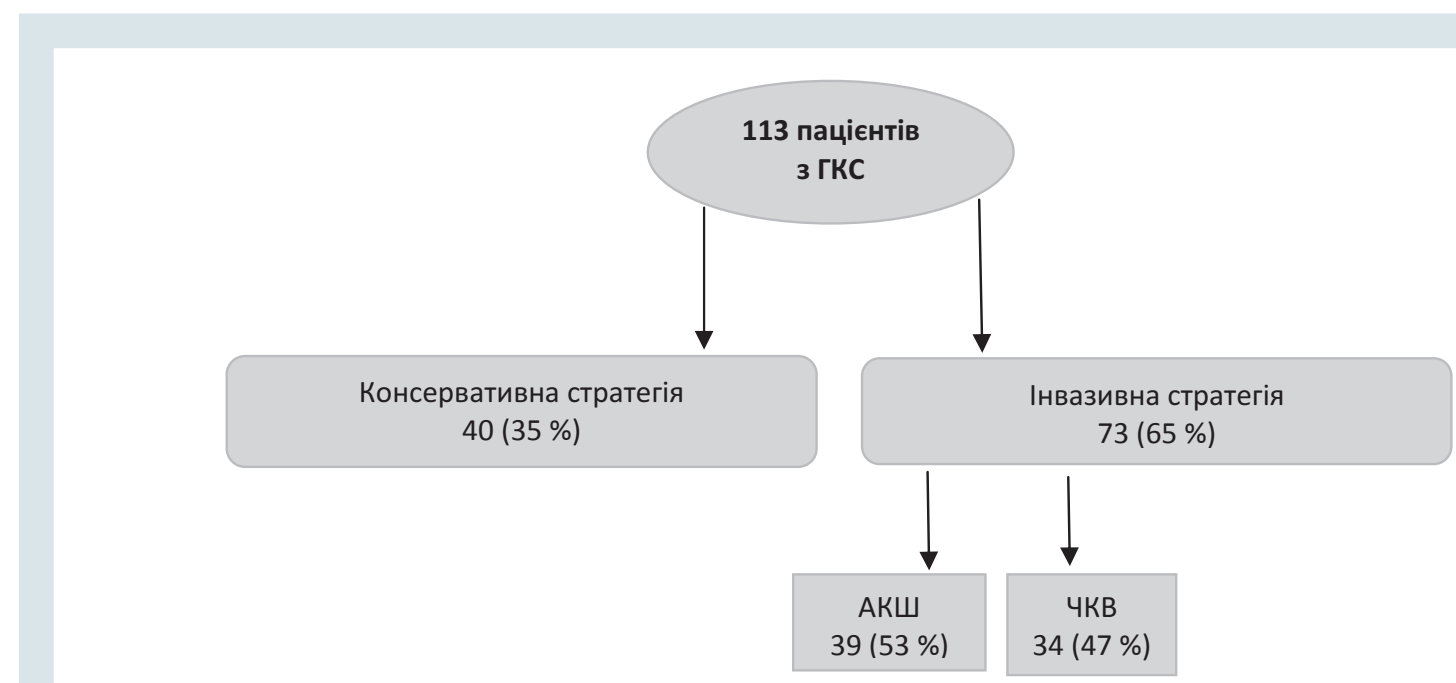

Рис. 1. Розподіл пацієнтів з гострим коронарним синдромом залежно від стратегії лікування 
фонного або особистого контакту. Медіана спостереження становила 20 (міжквартильний розмах 12-25) міс.

Ехокардіографічне дослідження протягом періоду госпіталізації здійснювали за стандартним протоколом, що передбачав оцінку фракції викиду (ФВ) лівого шлуночка за методом Сімпсона.

Коронарографію виконували зі стандартного стегнового або плечового підходів. За значущий стеноз вінцевих артерій приймали $\geq 70$ \% звуження їх просвіту. Залежно від кількості значуще стенозованих основних вінцевих артерій (лівої передньої низхідної, лівої обвідної та правої) діагностували хворобу 1, 2 або 3 вінцевих судин, при звуженні $>2$ вінцевих судин діагностували багатосудинне ураження. Значущий стеноз лівої загальної вінцевої артерії діагностували при $\geq 50$ \% звуженні її просвіту та класифікували як хворобу двох вінцевих судин.

Первинними кінцевими точками були серцеві події (серцева смерть, нефатальний IM), враховували також вторинні кінцеві точки - повторні госпіталізації, відновлення або погіршання симптомів (нестабільна стенокардія), потреба в реваскуляризації міокарда.

Статистичну обробку здійснено за допомогою програми Statistica v.8.0 (StatSoft, Inc, США). Середні величини подано як середнє арифметичне та стандартне відхилення або медіана (міжквартильний розмах). Неперервні змінні порівнювали за допомогою t-тесту або тесту ANOVA. Відмінності між відсотками чи категорійними змінними оцінювали за допомогою тесту $\chi^{2}$. Порівняння виживання між групами здійснювали за допомогою логарифмічного рангового критерію. Предиктори прогнозу встановлювали за допомогою методу інтенсивних пропорційностей Кокса. Результати вважали статистично значущими при значенні $\mathrm{p}<0,05$.

\section{Результати}

Основні вихідні клінічні й ангіографічні характеристики пацієнтів узагальнено в таблиці. Багатосудинне ураження виявлено у 46 (41\%) пацієнтів, у 29 (26 \%) - діагностовано бівазальне ураження. Серед пацієнтів, підданих інвазивній стратегії лікування, спостерігалася висока частка осіб, яким проведено АКШ (n = 39/73; 53 \%). Серед підданих АКШ переважали пацієнти із багатосудинним коронарним ураженням $(\mathrm{p}<0,0001) .3$ другого боку, більшості хворих iз багатосудинним ураженням також виконано АКШ (n = 33/46, 71 \%). Вихідна фракція викиду (ФB) була погранично нижчою у групі консерва- тивно лікованих пацієнтів, ніж у групі інвазивної стратегіï $((50,20 \pm 12,44)$ проти $(54,47 \pm 11,12) \%$; $\mathrm{p}=0,09)$, однак відсоток хворих зі зниженою систолічною функцією міокарда лівого шлуночка $(\Phi В<40 \%)$ був подібним в усіх групах (5 (12\%) осіб у групі консервативного лікування порівняно з 3 (8 \%) у групі АКШ і 2 (6 \%) у групі ЧКВ; $\mathrm{p}=0,58$ ).

Комбінована кінцева точка (усі подіі). Загалом виживання, вільне від подій (смерті, IM, нестабільної стенокардії чи повторної госпіталізації) протягом періоду спостереження становило 59 \%. Частота цих подій була статистично значуще вищою $(\mathrm{p}=0,03)$ серед пацієнтів, які отримували лише медикаментозну терапію, порівняно з тими, яким було здійснено АКШ (рuс. 2), і погранично вищою $(\mathrm{p}=0,08)$ порівняно з групою ЧКВ. Вільне від подій виживання між обома інвазивно лікованими групами (АКШ і ЧКВ) статистично значуще не відрізнялося $(\mathrm{p}=0,81)$. Ефективність інвазивної або неінвазивної стратегії не залежала від кількості уражених вінцевих артерій, виявлених при коронароангіографії.

Вторинні кінцеві точки або м'які події (нестабільна стенокардія, повторна госпіталізація з приводу нестабільної стенокардіi). Інвазивна стратегія мала переваги над консервативним веденням щодо частоти виникнення м'яких подій (відношення ризиків (ВР) 2,91; р = 0,02). Ці події реєструвалися суттєво рідше $(\mathrm{p}=0,04)$ у групі АКШ порівняно з групою консервативного (медикаментозного) лікування (рис. 3). Водночас аналіз у підгрупах виявив, що переваги АКШ перед медикаментозним лікуванням спостерігалися лише серед пацієнтів, у яких при госпіталізації діагностовано нестабільну стенокардію $(\mathrm{p}=0,03)$, IM без підйому сегмента ST $(\mathrm{p}=0,04)$, але не серед хворих із діагностованим IM із підйомом сегмента ST $(\mathrm{p}=0,87)$. Відмінність між консервативно лікованою групою та групою ЧКВ щодо частоти виникнення м'яких подій була погранично статистично значущою $(\mathrm{p}=0,08)$, i не спостерігалося статистично значущої різниці між двома інвазивними підходами.

Первинні кінцеві точки або тяжкі події (смерть і нефатальний IM). За період спостереження зареєстровано 6 смертей (з яких 5 класифіковано як серцеві) та 5 нефатальних IM. Частота цих подій була зіставною в усіх групах.

Вплив клінічних, ехокардіографічних та ангіографічних змінних. Аналіз інтенсивних пропорційностей Кокса із залученням початкової ФВ, кількості значуще звужених вінцевих артерій, супутнього ураження периферійних артерій, артеріальної гіпертензії, цукрового діабету 2-го типу, рівня холестерину ліпопротеїнів низької 
Таблиця

Демографічні, клінічні та ангіографічні характеристики хворих, які перенесли гострий коронарний синдром

\begin{tabular}{|c|c|c|c|}
\hline \multirow{2}{*}{ Показник } & \multirow{2}{*}{$\begin{array}{l}\text { Консервативна } \\
\text { стратегія }(n=40)\end{array}$} & \multicolumn{2}{|c|}{ Інвазивна стратегія (n = 73) } \\
\hline & & АКШ $(n=39)$ & ЧКВ $(n=34)$ \\
\hline \multicolumn{4}{|l|}{ Демографічні, клінічні дані } \\
\hline Вік, роки & $73,33 \pm 2,14$ & $74,31 \pm 2,74$ & $74,42 \pm 3,15$ \\
\hline Чоловіча стать & $24(60 \%)$ & $24(62 \%)$ & $26(76 \%)$ \\
\hline Спостереження, місяці & $19(12-25)$ & $24(12-25)$ & $17(6-25)$ \\
\hline Фракція викиду, \% & $50,20 \pm 12,44$ & $53,97 \pm 12,05$ & $55,00 \pm 10,20$ \\
\hline Нестабільна стенокардія & $18(45 \%)$ & $26(67 \%)$ & $18(53 \%)$ \\
\hline IM без підйому сегмента ST & $6(15 \%)$ & $5(13 \%)$ & $8(24 \%)$ \\
\hline IM з підйомом сегмента ST & $16(40 \%)$ & $8(20 \%)$ & $8(24 \%)$ \\
\hline \multicolumn{4}{|l|}{ Фактори ризику } \\
\hline Неконтрольована АГ & $9(22 \%)$ & $6(15 \%)$ & $2(6 \%)$ \\
\hline Контрольована АГ & $26(65 \%)$ & $26(67 \%)$ & $25(74 \%)$ \\
\hline Цукровий діабет 2-го типу & $8(20 \%)$ & $8(20 \%)$ & $7(21 \%)$ \\
\hline Куріння & $17(42 \%)$ & $22(56 \%)$ & $21(62 \%)$ \\
\hline Загальний холестерин, ммоль/л & $4,72 \pm 1,47$ & $5,40 \pm 1,32$ & $5,04 \pm 1,26$ \\
\hline Холестерин ЛПНГ, ммоль/л & $2,80 \pm 1,15$ & $3,33 \pm 1,10$ & $3,02 \pm 1,03$ \\
\hline \multicolumn{4}{|l|}{ Анамнез } \\
\hline Перенесений IM & $3(8 \%)$ & $8(20 \%)$ & $6(18 \%)$ \\
\hline Реваскуляризація в анамнезі & $2(5 \%)$ & 0 & $3(9 \%)$ \\
\hline Ураження периферійних артерій & $15(38 \%)$ & $18(46 \%)$ & $13(38 \%)$ \\
\hline \multicolumn{4}{|l|}{ Ангіографічні дані } \\
\hline Односудинне ураження & $7(18 \%)$ & 0 & $18(53 \%)^{* *}$ \\
\hline Двосудинне ураження & $11(28 \%)$ & $6(15 \%)$ & $12(35 \%)$ \\
\hline Багатосудинне ураження & $9(22 \%)$ & $33(85 \%)$ & $4(12 \%)^{* *}$ \\
\hline \multicolumn{4}{|l|}{ Медикаментозна терапія } \\
\hline Нітрати та їх похідні & $19(48 \%)$ & $8(21 \%)$ & $14(40 \%)^{*}$ \\
\hline Бета-адреноблокатори & $35(88 \%)$ & $34(90 \%)$ & $32(94 \%)$ \\
\hline Блокатори кальцієвих каналів & $33(82 \%)$ & $30(77 \%)$ & $30(88 \%)$ \\
\hline Інгібітори АПФ & $30(75 \%)$ & $25(64 \%)$ & $23(68 \%)$ \\
\hline Статини & $22(55 \%)$ & $27(69 \%)$ & $24(71 \%)$ \\
\hline Діуретики & $18(45 \%)$ & $20(51 \%)$ & $13(38 \%)$ \\
\hline Ацетилсаліцилова кислота & $27(67 \%)$ & $26(67 \%)$ & $27(79 \%)$ \\
\hline
\end{tabular}

Категорійні показники наведено як кількість випадків і частка, кількісні - у вигляді M \pm SD. Різниця показників статистично значуща порівняно з такими в пацієнтів, яким було проведено консервативне лікування: * $p=0,03$; ** $p<0,0001$ (тест $\chi^{2}$ ). АГ - артеріальна гіпертензія; АПФ - ангіотензинперетворювальний фермент; ЛПНГ - ліпопротеїни низької густини.

густини показав, що низька ФВ (< 40 \%) була єдиним предиктором усіх подій у цілій популяції дослідження (ВР 4,06; р = 0,008). Низька ФВ (< 40 \%) була також предиктором розвитку нестабільної стенокардії впродовж періоду спостереження (ВР 5,80; p = 0,0003). Крім того, низька $(<40 \%)$ ФВ (BР 7,59; p =0,009) та ураження периферійних артерій (BP 4,89; р = 0,04) були предикторами виникнення тяжких подій.

\section{Обговорення}

У цьому дослідженні представлені результати лікування пацієнтів похилого віку в реальній 


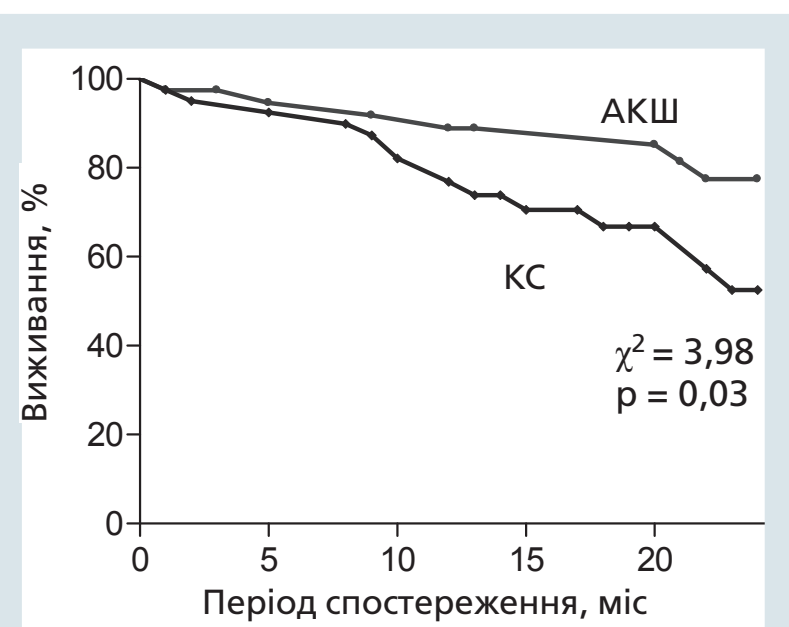

Рис. 2. Вільне від подій кумулятивне виживання (метод Каплана - Мейєра) пацієнтів 3 гострим коронарним синдромом, підданих консервативній стратегії (КС) та аортокоронарному шунтуванню

клінічній практиці. Серед хворих спостерігалася висока частка пацієнтів із багатосудинним ураженням. Ці пацієнти навіть у світлі останніх настанов щодо реваскуляризації міокарда [12] становлять проблемну групу, оскільки немає проспективних досліджень, присвячених вибору оптимальної стратегії іх реваскуляризації при ГКС без підйому сегмента ST, а при IM з підйомом сегмента ST після втручання на інфарктзалежній артерії залишається відкритим питання досягнення повної реваскуляризації [8]. 3 іншої точки зору, вища частка осіб із багатосудинним ураженням у групі пацієнтів, підданих хірургічній стратегії, цілком закономірна, оскільки АКШ є ефективним методом лікування хворих із ураженням багатьох вінцевих артерій, які залишаються симптомними, незважаючи на медикаментозне лікування. Ми припускаємо, що недостатня ефективність інвазивної стратегії лікування в пацієнтів похилого віку пов'язана із такими загальновідомими чинниками, як рестеноз/тромбоз стента у групі ЧКВ або стеноз/оклюзія шунта у групі АКШ. Крім того, в таких хворих завжди висока ймовірність неповної реваскуляризації: у пацієнтів похилого віку із багатосудинним ураженням дифузного характеру або тотальними оклюзіями повної реваскуляризації часто технічно неможливо досягти. Останнє своєю чергою стає причиною резидуальної ішемії та відновлення симптомів, які можливо контролювати лише медикаментозно. Тим не менше, при інвазивній стратегії лікування спостерігалися переваги щодо запобігання відновленню симптомів; це, правдоподібно, обумовлено оптимальними критеріями при виборі стратегії лікування. Також

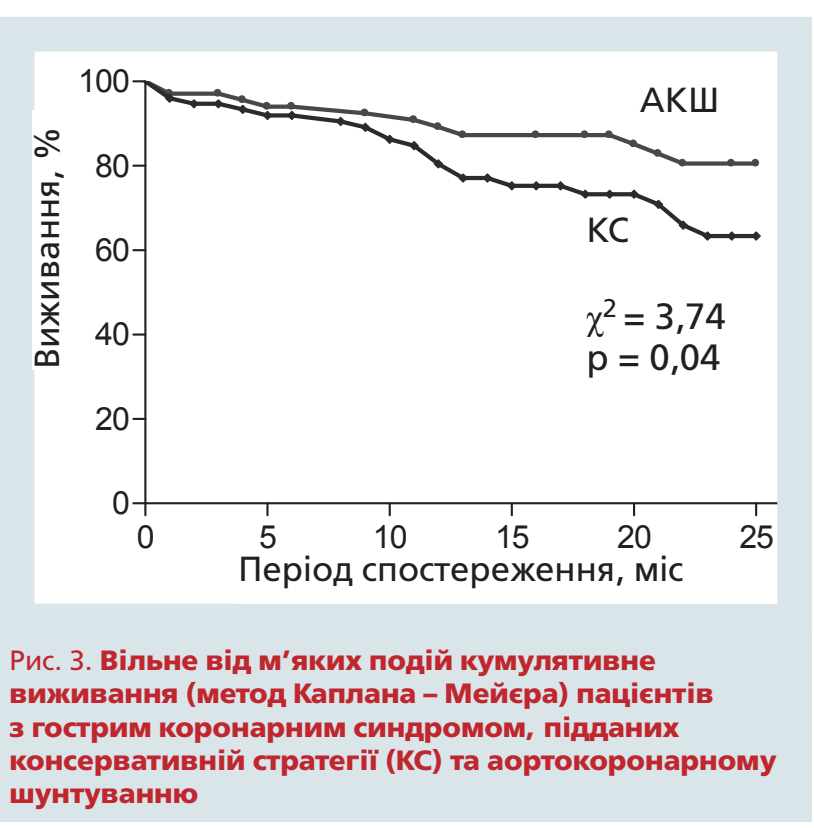

варте уваги, що протягом періоду спостереження серед пацієнтів, яким проведено АКШ, була найменшою частка осіб, які застосовували нітрати (див. таблищю).

На сьогодні опубліковані результати двох рандомізованих досліджень [18, 19] щодо ведення пацієнтів похилого віку із IM без підйому сегмента ST із суперечливими висновками, ще деякі дослідження тривають $[11,16]$. В одному із опублікованих досліджень [18] аналіз, проведений за участю 313 пацієнтів віком $\geq 75$ років, показав відсутність переваг рутинної інвазивної стратегії порівняно із селективною інвазивною стратегією, яка полягала в медикаментозній терапії й проведенні коронароангіографії лише при персистуванні симптомів ішемії (коронароангіографію було проведено 29 \% пацієнтам із групи селективної інвазивної стратегії). В іншому дослідженні [19], до якого залучили 457 пацієнтів віком $\geq 80$ років, показано статистично значущі переваги рутинної інвазивної стратегії порівняно зі строго консервативною стратегією (хворим із цієї групи проводили лише медикаментозну терапію, жодному з них не виконували коронароангіографію). При цьому автори зазначають, що ефективність інвазивної стратегії зменшувалася з віком, і неможливо зробити висновки щодо ефективності інвазивної стратегії в пацієнтів віком понад 90 років через малий розмір вибірки $(\mathrm{n}=34)$.

3 іншого боку, стратифікація ризику пацієнтів похилого віку після перенесеного ГКС та виявлення резидуальної ішемії також залишається дискусійною. Якщо розглядати стрес-тест із фізичним навантаженням, то пацієнти похи- 
лого віку не можуть, зазвичай, розвинути навантаження прийнятного рівня. Фармакологічні стрес-тести теж не настільки доступні, щоб охопити всіх пацієнтів. Проблемною є і оцінка резидуальної ішемії при зниженій фракції викиду. Беручи до уваги ці міркування, а також власні результати, вважаємо, що коронароангіографія повинна бути ключовою процедурою для вирішення питання щодо стратегії ведення пацієнтів похилого віку після перенесеного ГКС. Підхід цей повинен бути індивідуалізований із урахуванням супутніх захворювань, функціонального статусу, якості життя і залежності від догляду $[17,20]$. Такий підхід може бути корисним для поліпшення віддаленого прогнозу (зменшення частоти тяжких подій), проте необхідна більша кількість пацієнтів для формулювання переконливих висновків.

Обмеження дослідження. Обмеження дослідження випливають із його обсерваційного характеру. Можливим обмеженням є те, що 3 позицій чинних зараз настанов частині хворих, яким було виконано АКШ, мало б бути проведено ЧКВ, а призначена медикаментозна антитромботична терапія була субоптимальною $[8,12,15]$.

\section{Конфлікту інтересів немає.}

\section{Література}

1. Antman E.M., Anbe D.T., Armstrong P.W. et. al. ACC/ AHA guidelines for the management of patients with ST-elevation myocardial infarction - executive summary. A report of the American College of Cardiology / American Heart Association Task Force on Practice Guidelines (Writing Committee to revise the 1999 guidelines for the management of patients with acute myocardial infarction) // J. Am Coll. Cardiol.- 2004.- Vol. 44.- P. 671-719. doi: 10.1016/j. jacc2004.07.002.

2. Bach R.G., Cannon C.P., Weintraub W.S, et al. The effect of routine, early invasive management on outcome for elderly patients with non-ST-segment elevation acute coronary syndrome // Ann. Intern. Med.- 2004.- Vol. 141 (3).- P. 186-195. doi: 10.7326/0003-4819-141-3-200408030-00007.

3. Braunwald E., Antman E.M., Beasley J.W. et al. ACC/AHA guidelines for the management of patients with unstable angina and non-ST-segment elevation myocardial infarction. A report of the American College of Cardiology/American Heart Association Task Force on Practice Guidelines (Committee on the Management of Patients With Unstable Angina) // J. Am. Coll. Cardiol.- 2000.- Vol. 36.- P. 970-1062. doi: 10.1016/S0735-1097(00)00889-5.

4. Delvin G. Women and elderly: subgroups under-represented in clinical trials // Curr. Opin. Cardiol.- 2010.- Vol. 25.- P. 335339. doi: 10.1097/HCO.0b013e328338bcab.

5. García-Blas S., Bonanad C., Sanchis J. Invasive strategy in elderly patients with acute coronary syndrome in 2018 : close to truth // J. Geriatr. Cardiol.- 2019.- Vol. 16.- P. 114120. doi: 10.11909/j.issn.1671-5411.2019.02.004.

6. Elbadawi A., Elgendy I.Y., Ha L.D. et al. National trends of percutaneous coronary intervention in patients $\geq 70$ years of age // Am. J. Cardiol.- 2019.- Vol. 123.- P. 701-703. doi: 10.1016/j.amjcard.2018.11.053.
Також відносно невелика кількість пацієнтів i, відповідно, відносно невелика кількість тяжких подій не дозволили дослідженню набути достатньої сили для отримання статистично значущих відмінностей між групами щодо первинних кінцевих точок.

\section{Висновки}

Аортокоронарне шунтування в пацієнтів похилого віку (віком $\geq 70$ років) з нестабільною стенокардією або з інфарктом міокарда без підйому сегмента ST, порівняно з консервативною стратегією, характеризується кращим виживанням, вільним від серцевих подій, зокрема, дозволяє ефективніше запобігати відновленню симптомів нестабільної стенокардії. Водночас інвазивна стратегія (аортокоронарне шунтування або черезшкірне коронарне втручання), порівняно 3 медикаментозним лікуванням, не зменшила частоти випадків серцевої смерті та нефатального інфаркту міокарда. Також у дослідженні не виявлено переваг черезшкірного коронарного втручання перед медикаментозним лікуванням або аортокоронарним шунтуванням.

7. Hordijk-Trion M., Lenzen M., Wijns W. et al. Patients enrolled in coronary intervention trials are not representative of patients in clinical practice: results from the Euro Heart Survey on Coronary Revascularization // Eur. Heart J.- 2006.Vol. 27 (6).- P. 671-678. doi: 10.1093/eurheartj/ehi731.

8. Ibanez B., James S., Agewall S. et al. for the ESC Scientific Document Group. 2017 Guidelines for the management of acute myocardial infarction in patients presenting with ST-segment elevation: The Task Force for the management of acute myocardial infarction in patients presenting with ST-segment elevation of the European Society of Cardiology (ESC) // Eur. Heart J.- 2018.- Vol. 39.- P. 119-177. doi: 10.1093/eurheartj/ehx393.

9. Lattuca B., Kerneis M., Zeitouni M. et al. Elderly patients with ST-segment elevation myocardial infarction: a patient-centered approach // Drugs Aging.- 2019. doi: 10.1007/s40266019-00663-y.

10. Lee P.Y., Alexander K.P., Hammill B.G. et al. Representation of elderly persons and women in published randomized trials of acute coronary syndromes // JAMA.- 2001.- Vol. 286 (6).P. 708-713. doi: 10.1001/jama.286.6.708.

11. Leng W.X., Yang J., Li W. et al. Rationale and design of the DEAR-OLD trial: randomized evaluation of routinely deferred versus EARly invasive strategy in elderly patients of 75 years or OLDer with non-ST-elevation myocardial infarction // Am. Heart J.- 2018.- Vol. 196.- P. 65-73. doi: 10.1016/j. ahj.2017.10.022

12. Neumann F.-J., Sousa-Uva M., Ahlsson A. et al. 2018 ESC/ EACTS Guidelines on myocardial revascularization: The Task Force on myocardial revascularization of the European Society of Cardiology (ESC) and European Association for Cardio-Thoracic Surgery (EACTS) // Eur. Heart J.- 2019.Vol. 40.- P. 87-165. doi: 10.1093/eurheartj/ehy394. 
13. Pfisterer M., Buser P., Osswald S. et al. Outcome of elderly patients with chronic symptomatic coronary artery disease with an invasive vs optimized medical treatment strategy: one-year results of the randomized TIME trial // JAMA.2003.- Vol. 289 (9).- P. 1117-1123. doi: 10.1001/ jama.289.9.1117.

14. Rich M.V., Chyun D.A., Skolnick A.H. et al. Knowledge gaps in cardiovascular care of the older adult population: a scientific statement from the American Heart Association, American College of Cardiology, and American Geriatrics Society // J. Am. Coll. Cardiol.- 2016.- Vol. 67 (20).- P. 24192440. doi: 10.1016/j.jacc.2016.03.004.

15. Roffi M. Patrono C. Collet J.-P. et al. 2015 ESC Guidelines for the management of acute coronary syndromes in patients presenting without persistent ST-segment elevation: Task Force for the management of acute coronary syndromes in patients presenting without persistent ST-segment elevation of the European Society of Cardiology (ESC) // Eur. Heart J.2016.- Vol. 37.- P. 267-315. doi: 10.1093/eurheartj/ehv320.

16. Sanchis J., Ariza-Solé A., Abu-Assi E. et al. Invasive versus conservative strategy in frail patients with NSTEMI: the
MOSCA-FRAIL clinical trial study design // Rev. Esp. Cardiol.2019.- Vol. 72 (2).- P. 154-159. doi: 10.1016/j.rec2018.02.007.

17. Sanchis J., Soler M., Núñez J. et al. Comorbidity assessment for mortality risk in elderly patients with acute coronary syndrome // Eur. J. Intern. Med.- 2019.- Vol. 62.- P. 48-53. doi: 10.1016/j.ejim.2019.01.018.

18. Savonitto S., Cavallini C., Petronio A.S. et al. Early aggressive versus initially conservative treatment in elderly patients with non-ST-segment elevation acute coronary syndrome: a randomized controlled trial // JACC Cardiovasc. Interv. 2012.- Vol. 5 (9).- P. 906-916. doi: 10.1016/j.jcin.2012.06.008.

19. Tegn N., Abdelnoor M., Aaberge L. et al. Invasive versus conservative strategy in patients aged after 80 years or older with non-ST-elevation myocardial infarction or unstable angina pectoris (After Eighty study): an open-label randomised controlled trial // Lancet.- 2016.- Vol. 387.- P. 10571065. doi: 10.1016/S0140-6736(15)01166-6.

20. Vincent L., Martínez-Sélles M. Frailty and acute coronary syndrome: does gender matter? // J. Geriatr. Cardiol.2019.- Vol. 16.- P. 138-144. doi: 10.11909/j.issn.16715411.2019.02.007.

\section{P.P. Коморовский}

Тернопольский национальный медицинский университет имени И.Я. Горбачевского

Фундация сердечно-сосудистых исследований, больница Сан Джакомо, Кастельфранко Венето, Италия

\section{Отдаленные исходы инвазивной и неинвазивной стратегий лечения у пациентов пожилого возраста с острым коронарным синдромом}

Цель работы - оценить отдаленные результаты консервативной и инвазивной стратегий лечения пациентов пожилого возраста с острым коронарным синдромом в реальной клинической практике.

Материалы и методы. Проведен анализ долгосрочных исходов лечения 113 последовательных пациентов в возрасте $\geq 70$ лет с острым коронарным синдромом. Конечные точки исследования - сердечная смерть или нефатальный инфаркт миокарда (ИМ), нестабильная стенокардия, повторная госпитализация.

Результаты. Выживание, свободное от конечных точек (смерти, ИМ, нестабильной стенокардии или повторной госпитализации), составило 59 \% через 20 (12-25) мес наблюдения. Частота достижения этих конечных точек была статистически значимо более высокой $(p=0,03)$ у пациентов, получающих только медикаментозную терапию по сравнению с теми, которым было выполнено аортокоронарное шунтирование (АКШ), и более высокой на уровне пограничной статистической значимости $(p=0,08)$ по сравнению с группой чрескожного коронарного вмешательства (ЧКВ). Выживание, свободное от конечных точек, статистически значимо не различалось $(p=0,81)$ между двумя инвазивными стратегиями (АКШ и ЧКВ). При этом мягкие события (нестабильная стенокардия, повторная госпитализация в связи с нестабильной стенокардией) в группе АКШ наблюдались статистически значимо реже $(p=0,04)$ по сравнению с группой медикаментозного лечения, а частота тяжелых событий (кардиальной смерти и нефатального ИМ) была сопоставимой во всех группах. Низкая фракция выброса (< 40 \%) и сопутствующее поражение периферических артерий, по данным анализа пропорциональных интенсивностей Кокса, проявили себя независимыми предикторами тяжелых событий.

Вывод. АКШ у пациентов пожилого возраста ( $\geq 70$ лет) по сравнению с консервативной стратегией, характеризуется лучшей выживаемостью, свободной от сердечно-сосудистых событий.

Ключевые слова: острый коронарный синдром, возраст, исход, реваскуляризация. 


\section{R.R. Komorovsky}

I. Horbachevsky Ternopil National Medical University, Ternopil, Ukraine Cardiovascular Research Foundation, S. Giacomo Hospital, Castelfranco Veneto, Italy

\section{Long-term results of invasive and non-invasive treatment strategies in the elderly patients with acute coronary syndrome}

The aim - to evaluate long-term outcomes of conservative (optimised medical therapy) versus revascularization strategy of elderly patients with acute coronary syndrome in a real world practice.

Materials and methods. Prospective analysis of event-free survival of 113 consecutive patients with acute coronary syndrome aged $\geq 70$ years. Study end-points: cardiac death, non-fatal myocardial infarction, unstable angina pectoris, re-hospitalisation.

Results. Overall, event-free survival (freedom from death, myocardial infarction, unstable angina or re-hospitalisation) was $59 \%$ at $20(12-25)$ months follow-up. The incidence of these events was significantly higher $(p=0.03)$ in patients receiving only medical therapy compared with those who underwent coronary artery bypass grafting surgery and borderline higher $(p=0.08)$ compared to percutaneous coronary intervention group patients. The event-free survival rates in both invasively treated groups of patients were not different $(p=0.81)$. The incidence of soft events, including unstable angina pectoris or re-hospitalisation, was significantly lower in the coronary artery bypass grafting group $(p=0.04)$ as compared with the medical therapy group, while the incidence of hard events (cardiac death and non-fatal myocardial infarction) was similar in all groups. According to Cox proportional hazard analysis, low ejection fraction $(<40 \%)$ and concomitant peripheral arterial disease were found to be independent predictors of hard events.

Conclusion. Coronary artery bypass grafting in the elderly (aged $\geq 70$ years) patients appears to be superior to conservative strategy in terms of event-free survival.

Key words: acute coronary syndrome, elderly, outcome, revascularization. 